\title{
LXV. Description of Mr. Phillips London's hydrometer; with remarks on the curing of mackerel for exportation or winter use
}

\section{Phillips London}

To cite this article: Phillips London (1816) LXV. Description of Mr. Phillips London's hydrometer; with remarks on the curing of mackerel for exportation or winter use, Philosophical Magazine Series 1, 47:217, 329-330, DOI: 10.1080/14786441608628472

To link to this article: http://dx.doi.org/10.1080/14786441608628472

曲 Published online: 27 Jul 2009.

Submit your article to this journal $[\pi$

Џll Article views: 3

Q View related articles $₫$ 
every engineer in this mechanical country; the only real credit, that can be acquired in this pursuit, will be given to those whor do actually realize the invention, and this will be due to each in dividual in proportion to the liberality with which he supports the undertaking.

Large individual subscriptions however are not necessary to obtain $1500 l$. and in fact subscriptions of one guinea are often more productive than those of a hundred. But whatever gentlemen may think proper to subscribe, whilst the subject is before them, I would request them to give notice of immediately, as by that means, and that alone, can any further step be taken before the subject will be forgotten.

$$
\text { I remain, sir, }
$$

Your obedient servant,

Brompton, April 5, 1816.

Gro. Caylex.

P.S.-The sketch represents an end view of a hydrogen gas balloon with three tiers of wing to be worked by the steanengine, or any other first mover; each wing to be divided into many stripes or portions, which are so constructed as to heel uj, and down by the alternate pressure of the air above and below them at each stroke of the engine, and thus by their oblique wait to propel the balloon.

LXV. Description of Mr. PhrLups London's Hydrometer; with Remarks on the curing of Mackercl for Exportation or WTinter Use**

Sir, - I herewrirh send you a half barrel of mackerel, part of twenty-five thousand mackerel cured on my plan; also Mr. Cutler's certificate, that so many were cured at Ramsgate during the last season, most of which were shipped for Russia. They were all cured by immersion in brine of British solid salt, agreeably to the method I had the honour of communicating to the Society, and which is printed in the thirty-second volume of the Society's Transactions, p.204. The whole were extremely fine, and full as beautiful as the speeimen sent, which I hope will meet the approbation of the Society. I am, sir, Your obedient servant,

No. 57, Cannon-strect, London, Phillips London. Feb. 14, 1815.

To C. Taylor, M.D. Sec.

* From Transactions of the Society for the Encouragement of Arts, Munarfectures and Commerce, vol. xxxiii. for 1815. - The Suciety's silver sicdil sct in gold was voted to $\mathrm{Mr}$. London for this communication.

From 
From Mr. London's statement at a meeting of the comnintte', it appears that the brine ought always to contain a redundancy of salt; in such case there is not the least danger of the finta putrefying or growing rancid, as the extra lnmps of solid salt in the brine immediately aet upon any watery or other liquors which proceed from the fish when inclosed in the cask. That the same process will also answer perfectly well for preserving beef or any animal food for sea store.

\section{Certificate.}

Mr. London cured by his new process under my immediate inspection upwards of 25,000 mackerel at Ramsgate, in Keit, during the last season.

Sept. 28, 1814.

John Cutlek, Licensed Fish Curer, at Ramsgate, hent.

\section{Reference to the Engraving of Mr. Los Dov's Hydrometer, Plate IV. fig. 3.}

This instrument consists of a glass bottle, with a ground-glass stopper, to be filled with brine made from a solution of solid salt in water; within it are three glass bubbles, $a, b, c$, of different specific gravities, so graduated that, supposing the temperature of the air to be at sixty degrees of Fahrenheit's thermometer, and only one bubble floats on the surface, as shown in the engraving at $a$, it indicates the specific gravity of the brine to be 1,155 , containing about 20 parts salt, and 80 of water, which is insufficient to cure animal matters with certainty by immersion in it.

When the second bubble, $c$, floats, it indicates the specific gravity of the brine to be 1,180 , or about 24 parts salt, and 76 parts water, which may be used for the purpose of immersion.

But when the three bubbles, $a, b, c$, float, they indicate the specific gravity to be 1,106 , or about 28 salt, and 72 water.

This brine will fully answer the purpose in the hottest weather in most climates, provided the rules be attended to which I had the honour to send to the Society last year, and the meat or fish always completely covered with the brine.

PHILLIPS LoNdoN. 
